Retention: Lifetime

\title{
Safety Evaluation of the Mixed Waste Storage Building (Building 643-43E) (U)
}

Author:

J. M. Pareizs

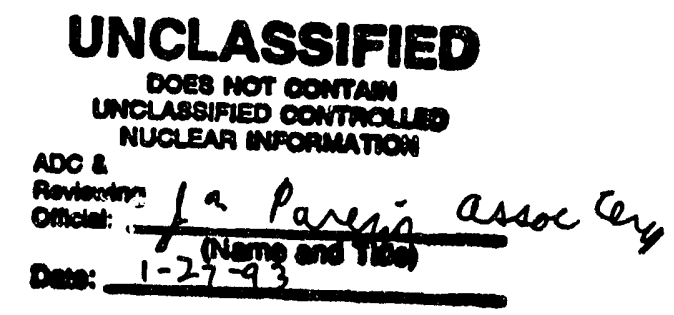

January 27, 1992

Westinghouse Savannah River Company Savannah River Technology Center Alken, SC 29808

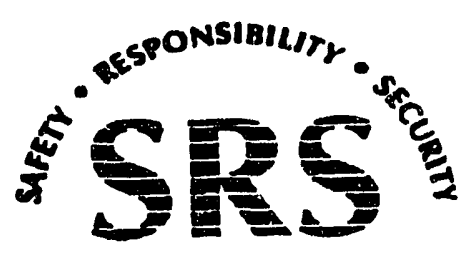

PREPARED FOR THE U.S. DEPARTMENT OF ENERGY UNDER CONTRACT NO. DE-ACJO-89SR18035

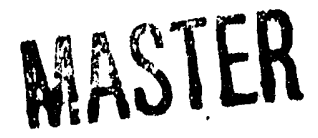


Project:

Document:

Title:
Mixed Waste Storage Building, 643-43E

WSRC-TR-93-024

Safety Evaluation of the Mixed Waste Storage Building (Building 643-43E) (U)

Approvals:

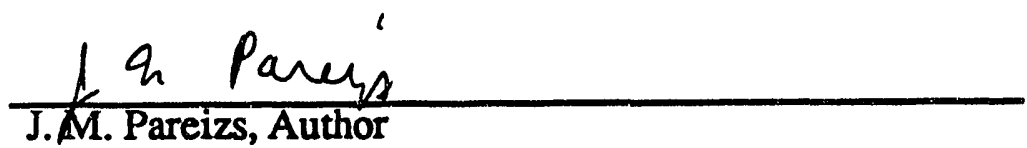

$$
\text { UB Oraoley }
$$

G. B. Woolsey, Techrical Reviewer

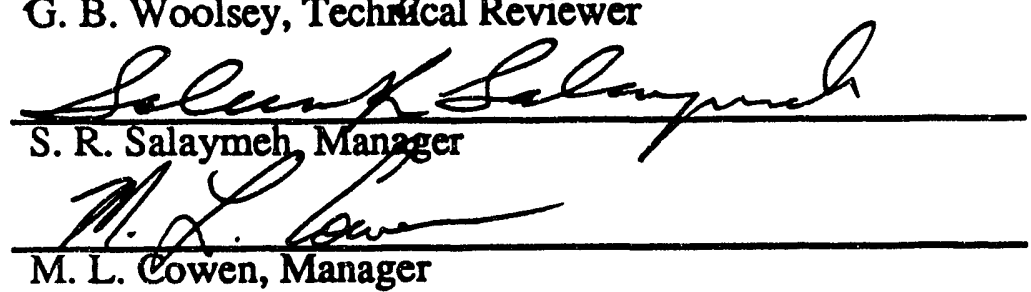

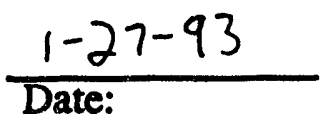

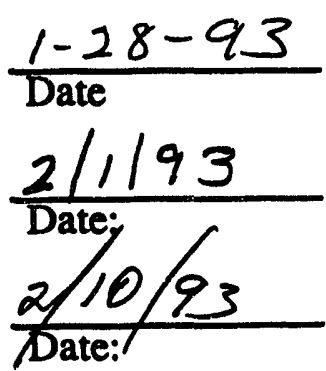


TABLE OF CONTENTS

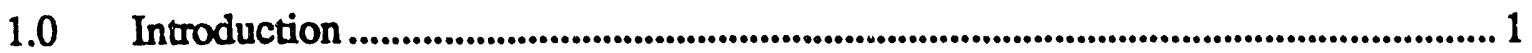

2.0 Facility Description ............................................................................................................. 1

3.0 Accident Analysis ............................................................................................................. 1

3.1 Analysis Method and Assumptions...................................................................... 1

3.2 Potential Accidents Evaluated ............................................................................. 3

3.3 Earthquakes............................................................................................................. 3

3.4 Drum Rupture . Internally Induced ................................................................ 5

3.5 Drum Rupture - Externally Induced.....................................................................7

3.6 Fires....................................................................................................................... 8

3.7 High Winds .................................................................................................................. 11

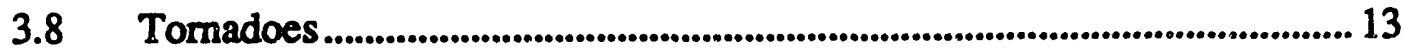

3.9 Criticality .................................................................................................................. 13

4.0 Conclusions ......................................................................................................................... 13

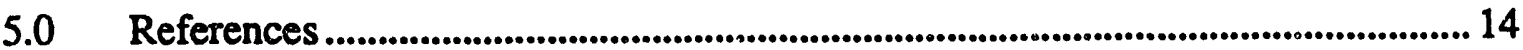


WSRC-TR-93-024

\section{LIST OF FIGURES}

Figure 1. Risks of the Solid Wasic Disposal Facility ........................................................... 15

Figure 2. Maximum Risks of SRS Facilities.......................................................................... 16 
WSRC-TR-93-024

\section{LIST OF TABLES}

Table 1. Summary Table ..................................................................................................... 17 
WSRC-TR-93-024

\subsection{INTRODUCTION}

A safety evaluation has been conducted for the Mixed Waste Storage Building (MWSB), 643-43E. The results of this evaluation are compared with those contained in the Burial Ground Safety Analysis Report (SAR). Building 643-43E will function as an interim storage facility for Resource Conservation and Recovery Act (RCRA) regulated mixed waste. It will meet all applicable standards set forth by the Environmental Protection Agency (EPA), the South Carolina Department of Health and Environment Control (SCDHEC), and Department of Energy (DOE) Orders.

\subsection{FACILITY DESCRIPTION}

The MWSB is located next to Building $643-29 \mathrm{E}$. It will provide a facility for interim storage of packaged hazardous waste and mixed hazardous and radioactive waste from operations at the Savannah River Site. The structure will be permitted according to provisions of the Resource Conservation and Recovery Act (RCRA).

Building 643-43E will be similar in all important respects to Buildings 643-29E and 709-2G; these buildings are being used to store the same types of waste that will be stored in Building 643-43E. The MWSB will be a 60 -foot by 160 -foot pre-engineered metal structure consisting of a steel I-beam frame and sheet metal roofing. It will be centered over a 50 -foot by 150-foot concrete pad. The sides of the building from grade to approximately 5-feet above grade will be chain link fence fastened to each steel column. Siding will be provided from the top of the fence to the roof line. The roof will be continuous without end joints from the eaves to the ridge, and all side joints will be sealed with closure strips at all wall and roof intersections [6].

Access to Building 643-43E for pedestriaus will be through four doors. In addition, one steel sectional overhead door will allow fork-lift access to the building.

The building's floor space will be occupied by various sized closed containers of waste that will be treated in either the HW/MW-Treatment Building or the Consolidated Incineration Facility (CIF) prior to final disposal at the HW/MW Disposal Facility Vaults. One type of waste expected in the MWSB is scintillation fluid that contains xylene. Since xylene is a flammable liquid and presents an extreme fire hazard if mitigating measures aren't taken, drums containing xylene are to be stored in concrete culverts. Examples of containers which might be stored in Building 643-43E include, but are not limited to, 55-gallon drums, B-6 boxes, B-12 boxes, B-25 boxes, and stainless steel welded boxes; some of these containers will be stacked two or three high.

\subsection{ACCIDENT ANALYSIS}

\subsection{Analysis Method and Assumptions}

Since Building 643-43E is an interim storage facility, its inventory cannot be assumed to remain constant, and, as a result, regular accident analysis methods are more difficult to apply. in the Hazards Assessment Document (HAD) [1] for the building, this fact is taken into consideration and a new method is developed that increases operational flexibility and controls the inventory so the facility can be classified as a Low Hazard Nuclear Facility. The initial step in the method is to assign a maximum allowable dose for a specific distance of interest downwind of the facility; an upper bound radiological dose of 4 REM for a 
maximum exposed individual located 100 meters downwind of the facility was specified in the HAD. The next step in the method involves choosing the worst case accident for analysis and determining specific dose conversion factors for each radionuclide. The dose conversion and airborne dispersion factors are computed from AXAIR-89Q information and are multiplied by the inventory of a specific radionuclide to give its dose contribution for a maximum exposed individual located 100 meters downwind of the facility. The total dose is obtained by adding all the individual dose contributions. Using this method, operating personnel at the facility recalculate the overall dose before accepting any new waste to insure that the worst case accident would not result in consequences that exceed the specified maximum allowable dose.

Since the complete inventory for the MWSB is unknown at this time, a safety assessment for this facility based on a specific inventory would be inappropriate. To accomplish a safety assessment for the MWSB, the radiological consequences of the accidents analyzed are based on the maximum allowable dose specified in the HAD rather than on a total inventory since the dose is invariable and the inventory is not. The maximum allowable dose used in the HAD applies to a maximum exposed individual located 100 meters downwind of the facility. Since a distance of interest in this safety assessment is also the shortest distance from the MWSB to the site boundary, the maximum allowable dose at the site boundary must be used as the basis for consequence analysis. A dose of $6.96 \times 10^{-3} \mathrm{REM}$ at the site boundary corresponds to the 4 REM dose at 100 meters downwind of the facility and is used as a basis for consequence analysis in this assessment.

Because the dose of $6.96 \times 10^{-3}$ REM pertains specifically to a fire in the facility, some adjustments must be made to it before it's used as a basis for consequence analysis of other accidents. The adjustments are necessary since a fire is considered to be the worst case accident and directly using the dose from a fire as if it applied to other accidents would lead to overestimates for the consequences of those accidents. The doses of interest for the radiological consequences in this analysis are obtained by adjusting the dose of $6.96 \times 10^{-3}$ REM by two factors: the Source Reduction Factor (SRF) adjustment factor and the inventory adjustment factor. The SRF adjustment factor corrects for the use of fire specific SRF values in the HAD analysis. It is the ratio of the SRF appropriate for a particular accident scenario to the SRF used in the HAD. The inventory adjustment factor is the ratio of the inventory participating in a given accident scenario to the total inventory considered in the HAD.

Although the waste stored at the MWSB could be contained in 55 gallon drums, B6 boxes, B12 boxes, B-25 boxes, or stainless steel welded boxes, this safety assessment assumes, unless otherwise stated, that the storage container is a 55 gallon drum. For this assessment, it is also assumed that 13 concrete culverts, each measuring $7 \mathrm{ft}$ in diameter, are used to store drums containing xylene and higher than average activity waste; this arrangement is consistent with current practice at Building 643-29E. Since each concrete culvert can house 14 drums, a total of 182 drums can be accommodated in this manner. In addition, it is assumed that the total number of drums stored in the facility is 3408; this is the number of drums allowed in the facility by permit. The drums located outside the concrete culverts are assumed to be arranged into units measuring 2 drums by 2 drums and palletized; the drums on a given pallet are assumed to be banded together, but not anchored to the pallet. The palletized drums are also assumed to be stacked 2 or 3 high. For conservatism, the spacing between adjacent pallets is neglected. Unless otherwise stated in this analysis, the maximum number of drums are assumed to be in the facility. 
WSRC-TR-93-024

\subsection{Potential Accidents Evaluated}

This assessment considered the same accidents as those considered in the Burial Ground SAR [2] for airborne releases. These are:

- Earthquakes

- Drum Rupture - Internally Induced

- Drum Rupture - Externally Induced

- Fires

- High Winds

- Tornadoes

- Criticality

The unintentional exhumation scenario, evaluated in the Burial Ground SAR, was not assessed since all the waste in this facility will be stored above ground. Groundwater release scenarios were also not assessed since the SAR found these risks to be at least three orders of magnitude less than the risks from the airborne release scenarios. Flooding is not evaluated because Building 643-43E is above the area's 100 year flood plain. Radionuclide and chemical releases from heavy rains is not considered because the facility is covered, and any water in the facility would drain to a sump.

\subsection{Earthquakes}

Radionuclides could potentially be released from Building 643-43E following a severe earthquake. At earthquake severity levels below the design level earthquake, having a peak horizontal ground acceleration of $0.11 \mathrm{~g}$, releases that result from structural deformation of the building are not expected; however, releases could occur from drum failure at these lower earthquake severity levels. Specifically, the drums on the second or third level of storage could possibly fall, rupture, and release radionuclides.

\subsubsection{Earthquake Intensity and Frequency}

The design basis earthquake for Building 643-43E, which has a low hazard classification, is one with a peak horizontal ground acceleration of $0.11 \mathrm{~g}$. The relationship between earthquake intensity and frequency at SRS has been developed by J. A. Blume and Associates [3]. Based on this relationship, the frequencies have been tabulated by Huang [4]. The frequency of an earthquake with a horizontal ground acceleration of $0.11 \mathrm{~g}$, as obtained from this tabulation, is $1.5 \times 10^{-3}$ per year.

\subsubsection{Earthquake Consequences}

During an earthquake which has a horizontal ground acceleration of $0.11 \mathrm{~g}$, neither the building structure nor the concrete culverts are expected to fail; therefore, consequences that would result from this type of structural damage are not considered in this analysis. In contrast since the drums are banded together and some of them are stacked, the possibility does exist for an entire pallet to fall from the second or third tier during an earthquake with the characteristics described earlier. For this analysis, it is conservatively assumed that $50 \%$ 
of the pallets from the third tier of storage and $10 \%$ of the pallets from the second tier of storage fall to the ground. In addition, it is assumed that 1 of the 4 drums on each pallet ruptures and spills its contents on the floor of the storage building. These assumptions are consistent with those in the Burial Ground SAR [2].

To calculate the dose at the site boundary for a maximum exposed individual, the $6.96 \times 10^{-3}$ REM upper bound is adjusted using the adjustment factors discussed earlier. Therefore, the SRF adjustment factor and the inventory adjustment factor must be calculated first in order to find the dose of interest for this accident scenario.

The SRFs for radionuclide release used in the HAD analysis were based on a fire as the worst case accident. In the event of an earthquake, radionuclides would become airborne by evaporation. Typical SRFs for evaporation are 100 times less than SRFs for fire [8]. Therefore, for this analysis, a conservative SRF adjustment factor of 0.1 is used.

Since the dose calculated in the HAD is based on involvement of the total inventory, the inventory adjustment factor used in this analysis is found by dividing the number of drums involved in this accident by the total number of drums (200/3408).

The following summarizes the dose calculation to a maximum exposed individual at the site boundary following an earthquake having a peak horizontal ground acceleration of $0.11 \mathrm{~g}$ :

$$
\begin{aligned}
& \begin{array}{l}
\text { Offsite max } \\
\text { individual dose }
\end{array}=\left(6.96 \times 10^{-3} \mathrm{REM}\right)(0.1)(200 / 3408) \\
& \begin{array}{l}
\text { Offsite max } \max \\
\text { individual dose }
\end{array}
\end{aligned}
$$

The dose to a maximum exposed individual 100 meters downwind of the facility is $2.4 \times 10^{-2}$ REM. The dose for the offsite population for this accident scenario is found to be 0.25 Person-REM while the dose for the onsite population is 0.12 Person-REM. (Consequences for this accident and other potential accidents evaluated for Building 643-43E are summarized in Table 1).

\subsubsection{Eurthquake Risk}

The risk for radiological release from an earthquake with a $0.11 \mathrm{~g}$ peak horizontal ground acceleration is characterized by the product of consequence and frequency. For the case of the maximum exposed individual at the site boundary, it is calculated to be $6.2 \times 10^{-8}$ REM/yr. For the maximum exposed individual located 100 meters downwind of the facility, it is $3.6 \times 10^{-5} \mathrm{REM} / \mathrm{yr}$. For the offsite and onsite population, it is calculated to be $3.8 \times 10^{-4}$ Person-REM/yr and $1.7 \times 10^{-4}$ Person-REM/yr respectively. (Risks for this accident and other potential accidents evaluated for Building 643-43E are summarized in Table 1).

\subsubsection{Chemical Consequences of an Earthquake}

The chemical consequence calculations for this analysis are based on an assumed fractional inventory distribution for the MWSB. The fractional inventory is the ratio of the inventory for a particular hazardous chemical to the total hazardous chemical inventory and is obtained from the types of waste expected at the HW/MW Treatment Building. From these assumptions, the fractional chemical inventory for this analysis is: 


$\begin{array}{ll}\text { Lead }(\mathrm{Pb}) & -9.59 \times 10^{-1} \\ \text { Trichloroethane (TCE) } & -2.97 \times 10^{-4} \\ \text { Xylene } & -2.41 \times 10^{-2} \\ \text { Freon } & -1.57 \times 10^{-2} \\ \text { Mercury }(\mathrm{Hg}) & -7.65 \times 10^{-4} \\ \text { Chromates }\left(\mathrm{CrO}_{3}\right) & -3.01 \times 10^{-6}\end{array}$

As seen from this distribution, lead is the dominant chemical constituent.

For the case of an earthquake, it has been established in the radionuclide analysis that 200 drums would be affected. For this analysis, it is assumed that the entire contents of the drums are spilled onto the concrete pad and that evaporation is the mode of transport for the chemicals. By using the assumed fractional distribution of hazardous chemicals along with the chemical densities, the amount of each hazardous chemical involved in the accident would be:

$\begin{array}{lll}\mathrm{Pb} & -419,360 \mathrm{~kg} \\ \mathrm{TCE} & -18.0 \mathrm{~kg} \\ \mathrm{Freon} & -3.2 \mathrm{~kg} \\ \mathrm{Hg} & -432 \mathrm{~kg} \\ \mathrm{CO}_{3} & -0.32 \mathrm{~kg}\end{array}$

Xylene is not included because the earthquake only affects drums outside of the concrete culverts. Of the chemicals listed, only TCE, Freon, and $\mathrm{Hg}$ are considered for this analysis since $\mathrm{Pb}$ and $\mathrm{CrO}_{3}$, which are solids at the temperatures involved, are not amenable to evaporative transport.

To find the air concentrations at the site boundary for the chemicals, a release rate must initially be calculated. The Air Force Model [5] is used to estimate the release rates for TCE and $\mathrm{Hg}$. The assumptions made while using the Air Force Model include: a wind speed of 1 $\mathrm{m} / \mathrm{s}$, a pool thickness of $5 \mathrm{~mm}$, and an outside air temperature of $32.2^{\circ} \mathrm{C}(95 \%)$. The release rate of Freon is estimated by its diffusion rate in air since it is a gas at the temperature involved in this analysis.

The estimated air concentrations at the site boundary are found to be well below the Immediately Dangerous to Life and Health (IDLH) limits. For TCE, the air concentration at the site boundary following an earthquake which affects the MWSB is estimated to be 0.002 $\mathrm{mg} / \mathrm{m}^{3}$ compared to the IDLH limit of $2775 \mathrm{mg} / \mathrm{m}^{3}$. For Freon, the air concentration at the site boundary under these circumstances is estimated to be $0.024 \mathrm{mg} / \mathrm{m}^{3}$ compared to the IDLH limit of $251,500 \mathrm{mg} / \mathrm{m}^{3}$. Finally for $\mathrm{Hg}$, the air concentration at the site boundary is estimated to be $4.4 \times 10^{-6} \mathrm{mg} / \mathrm{m}^{3}$ compared to the IDLH limit of $28 \mathrm{mg} / \mathrm{m}^{3}$.

As a result of this analysis, the chemical consequences of an earthquake that affects the MWSB are not very significant.

\subsection{Drum Rupture. Internally Induced}

The Burial Ground SAR considered the possibility of internally induced drum rupture caused by alpha radiolysis of drummed waste and the resulting generation of hydrogen. As discussed in the SAR, an explosive concentration should not build up in drums that have a low curie content. Despite the drums in the Burial Ground having a low curie content, the analysis in the SAR conservatively assumed the possibility of internally induced drum 
rupture. Since the waste to be stored in Building 643-43E will have an even smaller alpha content than the waste considered in the Burial Ground SAR, the possibility of an internally induced drum rupture in this facility is even less than for the TRU waste in the Burial Ground. Even so, this analysis conservatively assumes the possibility of internally induced drum rupture for Building 643-43E and uses the same logic for the scenario as that used in the Burial Ground SAR.

\subsubsection{Internally Induced Drum Rupture Frequency}

The frequency used in the Burial Ground SAR for internally induced drum rupture is $2.1 \mathrm{x}$ $10^{-2}$ per year. Even though this frequency applies to TRU drums which contain more alpha decaying waste than that which will be stored in drums at the MWSB, this analysis assumes that the frequency is applicable for the MWSB. By linear scaling with the reduced quantity of drums in Building 643-43E that store alpha decaying waste (approximately 21 versus 3170 for exposed TRU drums in the Burial Ground SAR), the frequency of internally induced drum rupture for this analysis is $1.4 \times 10^{-4}$.

\subsection{Internally Induced Drum Rupture Consequences}

As in the Earthquake accident scenario, radionuclides would become airborne via evaporation. Therefore, an SRF adjustment factor of 0.1 is applied to the dose from the HAD.

Since the waste to be stored in Building 643-43E has such a low curie content, this analysis conservatively assumes that one drum in the facility ruptures as a result of hydrogen build-up from alpha radiolysis of cellulosic material. For this analysis, the inventory adjustment factor is one divided by 3408 .

The following summarizes the dose calculation to a maximum exposed individual at the site boundary following an internally induced drum rupture:

$\begin{aligned} & \text { Offsite max } \\ & \text { individual dose }\end{aligned}$
$\begin{aligned} & \text { Offsite max } \\ & \text { individual dose }\end{aligned}=2.0 \times 10^{-7} \mathrm{REM}$

The dose to a maximum exposed individual 100 meters downwind of the facility.is $1.2 \times 10^{-4}$ REM. The dose for the offsite population for this accident scenario is found to be $1.3 \times 10^{-3}$ Person-REM while the dose for the onsite population is $6.0 \times 10^{-4}$ Person-REM. (Consequences for this accident and other potential accidents evaluated for Building 643-43E are summarized in Table 1).

\subsubsection{Internally Induced Drum Rupture Risk}

The risk for radiological release from an internally induced drum rupture is characterized by the product of consequence and frequency. For the case of the maximum exposed individual at the site boundary, it is calculated to be $2.9 \times 10^{-11} \mathrm{REM} / \mathrm{yr}$. For the maximum exposed individual located 100 meters downwind of the facility, it is $1.7 \times 10^{-8} \mathrm{REM} / \mathrm{yr}$. For the offsite and onsite population, it is calculated to be $1.8 \times 10^{-7}$ Person-REM/yr and $8.4 \times 10^{-8}$ 
Person-REM/yr respectively. (Risks for this accident and other potential accidents evaluated for Building 643-43E are summarized in Table 1).

\subsubsection{Chemical Consequences of Internally Induced Drum Rupture}

The chemical consequences for the internally induced drum rupture scenario are not specifically calculated, but if they were, the procedure would be the same as that outlined in the earthquake analysis. Referring to the chemical consequences for the earthquake scenario, the air concentrations found were well below the recommended IDLH limits. Since only 1 drum would be involved in the internally induced drum rupture scenario, it is reasoned that the air concentrations would be far less than those found in the earthquake analysis which considered 50 drums. For this reason, the chemical consequences were not considered significant for the internally induced drum rupture accident.

\subsection{Drum Rupture - Externally Induced}

Drum damage can result from corrosion during storage, from mishandling during transport, or from accidents near the facility. Corrosion problems have occurred in TRU waste drums stored on open concrete pads, but this corrosion resulted from either water ingress or from water vapor condensation in the annulus between the polyethylene liner and the drum. The corrosion occurred in the lids of 6 out of approximately 10,000 drums over a 5 year time period. Since the drums stored in Building 643-43E will have a roof over them, water ingress is not considered to be a serious threat. In addition, the liquid waste stored in Building $643-43 \mathrm{E}$ is not acidic in nature, so a corrosion environment does not exist. Also, the drums in which the liquid waste is stored are not vented, so water vapor cannot enter from the outside. Based on these considerations, drum corrosion is not considered for this analysis.

Mishandling can result in drums being dropped, crushed, punctured, or dented.

Equipment failure or human error near the MWSB could cause building and drum damage resulting in a release. A search of the Waste Management Fault Tree Data Bank indicated that $25 \%$ of building $643-29 \mathrm{E}$ was damaged when a truck crane, which was setting up to operate, tipped and caused the boom to collapse onto the building.

\subsubsection{Externally Induced Drum Rupture Frequency}

The Burial Ground SAR reported a frequency for drum rupture from mishandling of one in fifty years. The frequency of a crane boom collapse is estimated by dividing the number of collapses by the number of years the Burial Ground has been in existence (one in forty years or $\left.2.5 \times 10^{-2} / \mathrm{yr}\right)$. Because the frequency of a collapse is more conservative than a mishandling accident, it is used for analysis.

\subsubsection{Externally Induced Drum Rupture Consequences}

The consequences considered for this analysis are based on the scenario in which a crane boom falls on the MWSB, destroying $25 \%$ of it. This scenario was chosen since it was considered to be more conservative than a mishandling accident in which only several drums would be damaged. It is assumed that $25 \%$ of the drums are ruptured in this accident. Therefore, the inventory adjustment factor is $852 / 3408$.

As in the earthquake accident scenario, radionuclides would become airborne via evaporation. In addition, the waste in the 55-gallon drums could become aerosolized due to 
the large amount of energy of a falling crane. Therefore, it is conservatively assumed that the SRF for this accident is the same as the SRF for in the HAD. This results in an SRF adjustment factor of 1.0 . The following summarizes the dose calculation to a maximum exposed individual at the site boundary following an externally induced drum rupture:

$\begin{aligned} & \text { Offsite max } \\ & \text { individual dose }\end{aligned}=\left(6.96 \times 10^{-3} \mathrm{REM}\right)(1.0)(852 / 3408)$
$\begin{aligned} & \text { Offsite max } \max \\ & \text { individual dose }\end{aligned}$

The dose to a maximum exposed individual 100 meters downwind of the facility is 1.0 REM. The dose for the offsite population for this accident scenario is found to be 11.1 Person-REM while the dose for the onsite population is 5.1 Person-REM. (Consequences for this accident and other potential accidents evaluated for Building 643-43E are summarized in Table 1).

\subsubsection{Externally Induced Drum Rupture Risk}

The risk for radiological release from an externally induced drum rupture is characterized by the product of consequence and frequency. For the case of the maximum exposed individual at the site boundary, it is calculated to be $4.3 \times 10^{-5} \mathrm{REM} / \mathrm{yr}$. For the maximum exposed individual located 100 meters downwind of the facility, it is $2.5 \times 10^{-2} \mathrm{REM} / \mathrm{yr}$. For the offsite and onsite population, it is calculated to be 0.28 Person-REM/yr and 0.13 PersonREM/yr respectively. (Risks for this accident and other potential accidents evaluated for Building $643-43 \mathrm{E}$ are summarized in Table 1).

\subsubsection{Chemical Consequences of Externally Induced Drum Rupture}

The chemical consequences for the externally induced drum rupture scenario are not specifically calculated, but if they were, the procedure would be the same as that presented in the earthquake analysis. Referring to the chemical consequences for the earthquake scenario, the air concentrations found were well below the recommended IDLH limits. Since onily 2 drums would be involved in the extemally induced drum rupture scenario, it is reasoned that the air concentrations would be even less than those found in the earthquake analysis which considered 50 drums. For this reason, the chemical consequences were not considered significant for the externally induced drum rupture accident.

\subsection{Fires}

Fires in drums could arise from spontaneous combustion, drum rupture, lightning, or vehicle crashes. As discussed in the SAR, seven small fires have occurred in the Burial Ground lowlevel waste trenches at SRS from 1955 to 1981 . No fires have occurred at SRS since TRU waste has been stored in drums, culverts, or steel engineered boxes. The observed low-level trench fires were attributed to spontaneous chemical combustion involving nitric acid. For this assessment, it is assumed that fire frequency and consequences follow the same general logic and assumptions used in the Burial Ground SAR.

\subsubsection{Fire Frequency}

Based on early experience with unconfined waste, the Burial Ground SAR calculated a frequency of $2.1 \times 10^{-2}$ per year for TRU drum fires on the pads. With a larger number of drums in Building 643-43E, the frequency of fires in drums outside of culverts is estimated to 
be $2.3 \times 10^{-2}$ per year by linear scaling. The frequency for a culvert fire in the MWSB is estimated by considering a number of factors including: the approximate number of packages to be placed in culverts each year, the total number of packages expected to be in culverts, and the amount of time each year the culverts will be open and therefore susceptible to fire. Based on these factors, the following calculation is made to estimate the frequency for a culvert fire in the MWSB:

$$
\begin{aligned}
& \text { Frequency }=\frac{(1 \mathrm{fire})(\# \text { of packages } / \mathrm{yr})(\# \text { of hours culvert is opened } / \mathrm{yr})}{\text { (total \# of packages expected)(Hours/yr) }} \\
& \text { Frequency }=\frac{(1 \text { fire })(42 \text { packages } / \mathrm{yr})(6 \mathrm{hrs} / \mathrm{yr})}{(182 \mathrm{packages})(8760 \mathrm{hrs} / \mathrm{yr})} \\
& \text { Frequency }=1.58 \times 10^{-4} / \mathrm{yr}
\end{aligned}
$$

This estimated frequency is consistent with that calculated in the Burial Ground SAR for TRU culvert fires.

\subsubsection{Fire Consequences}

Since metal containers will be used to store waste in Building 643-43E, the consequences of a fire are reduced when xylene is not present. The spread of fire would be less severe under these circumstances and fewer containers would be involved. In addition, water trucks are available at the Burial Ground to extinguish any fires. For these reasons, it is assumed that a fire outside of the concrete culverts would be limited to a single container. Since B-25 boxes will be used to store waste at this facility, it is more conservative to consider its capacity for this analysis rather than the 55-gallon drum's. Instead of determining the number of B-25 boxes that could fit into the storage space, this assessment considers 13 drums to be equivalent in capacity to one B-25 box; therefore, the inventory adjustment factor for this analysis is found by dividing 13 by 3408 . As in the Burial Ground SAR, it is assumed that only $1 \%$ of the waste in the container becomes airborne. Since the radionuclides stored outside of concrete culverts are involved, the SRF adjustment factor used is $0.01 / 0.001$. The following summarizes the dose calculation to a maximum exposed individual at the site boundary following a fire in a container located outside the concrete culverts:

$$
\begin{aligned}
& \begin{array}{l}
\text { Offsite max } \\
\text { individual dose }
\end{array} \\
& \begin{array}{l}
\text { Offsite max } \\
\text { individual dose }
\end{array}=2.7 \times 10^{-4} \mathrm{REM}
\end{aligned}
$$

The dose to a maximum exposed individual 100 meters downwind of the facility is $1.5 \times 10^{-1}$ REM. The dose for the offsite population for this accident scenario is found to be 1.61 Person-REM while the dose for the onsite population is $7.9 \times 10^{-1}$ Person-REM.

For the waste stored inside concrete culverts with xylene, a fire would be more severe. In this analysis, it is assumed that the fire would be contained to a single culvert with 14 drums involved. This is a reasonable assumption since having more than one culvert open at a time is a rarity and since the thickness of the culvert precludes the fire from spreading outside its bounds. The inventory adjustment factsor for this scenario is found by dividing 14 by 3408 . As before, it is assumed that only $1 \%$ of the waste in the container becomes airborne. Since 
the radionuclides stored inside of concrete culverts in Building 643-43E are involved, the SRF adjustment factor used for this analysis is $0.01 / 0.0001$. The following summarizes the dose calculation to a maximum exposed individual at the site boundary following a fire in a concrete culvert:

$$
\begin{aligned}
& \begin{array}{l}
\text { Offsite max } \\
\text { individual dose }
\end{array}=\left(6.96 \times 10^{-3} \mathrm{REM}\right)(0.01 / 0.0001)(14 / 3408) \\
& \begin{array}{l}
\text { Offsite max } \\
\text { individual dose }
\end{array}=2.9 \times 10^{-3} \mathrm{REM}
\end{aligned}
$$

The dose to a maximum exposed individual 100 meters downwind of the facility is 1.65 REM. The dose for the offsite population for this accident scenario is found to be 17.6 Person-REM while the dose for the onsite population is 8.4 Person-REM. (Consequences for this accident and other potential accidents evaluated for Building 643-43E are summarized in Table 1).

\subsubsection{Fire Risk}

The risk for radiological release from a fire is characterized by the product of consequence and frequency. To obtain the fire risk, the risks for the individual cases considered in the fire analysis are summed. For the case of the maximum exposed individual at the site boundary, it is calculated to be $6.7 \times 10^{-6} \mathrm{rem} / \mathrm{yr}$. For the maximum exposed individual located 100 meters downwind of the facility, it is $3.8 \times 10^{-3} \mathrm{REM} / \mathrm{yr}$. For the offsite and onsite populations, it is calculated to be $4.0 \times 10^{-2}$ Person-REM/yr and $1.9 \times 10^{-2}$ Person-REM/yr respectively. (Risks for this accident and other potential accidents evaluated for Building 643-43E are summarized in Table 1).

\subsubsection{Chemical Consequences of a Fire}

The chemical consequence calculations for this analysis are based on an assumed fractional inventory distribution for the MWSB. The fractional inventory is the ratio of the inventory for a particular hazardous chemical to the total hazardous chemical inventory and is obtained from the types of waste expected at the HW1MW Treatment Building. From these assumptions, the fractional chemical inventory for this analysis is:

$\begin{array}{ll}\mathrm{Pb} & -9.59 \times 10^{-1} \\ \text { TCE } & -2.97 \times 10^{-4} \\ \text { Xylene } & -2.41 \times 10^{-2} \\ \text { Freon } & -1.57 \times 10^{-2} \\ \mathrm{Hg} & -7.65 \times 10^{-4} \\ \mathrm{CrO}_{3} & -3.01 \times 10^{-6}\end{array}$

As seen from this distribution, lead is the dominant chemical constituent.

For the case of a fire, it has been established in the radionuclide analysis that 13 drums outside the concrete culverts would be affected. For this analysis, it is assumed that the drums' contents are leaked onto the concrete pad where they burn. By using the assumed fractional distribution of hazardous chemicals along with the chemical densities, the amount of each hazardous chemical involved in the fire would be: 


$$
\begin{array}{lll}
\mathrm{Pb} & - & 27,263 \mathrm{~kg} \\
\mathrm{TCE} & - & 1.2 \mathrm{~kg} \\
\mathrm{Freon} & - & 0.2 \mathrm{~kg} \\
\mathrm{Hg} & - & 28.3 \mathrm{~kg} \\
\mathrm{CrO}_{3} & - & 0.02 \mathrm{~kg}
\end{array}
$$

To find the air concentrations at the site boundary for the chemicals, the release rates that were computed in the HAD fire analysis are used.

As in previous scenarios, the estimated air concentrations at the site boundary are found to be well below the Immediately Dangerous to Life and Health (IDLH) limits. For TCE, the air concentration at the site boundary following a fire outside the concrete culverts at the MWSB estimated to be $4.7 \times 10^{-4} \mathrm{mg} / \mathrm{m}^{3}$ compared to the IDLH limit of $2775 \mathrm{mg} / \mathrm{m}^{3}$. For Freon, the air concentration at the site boundary under these circumstances is estimated to be $6.3 \times 10^{-2}$ $\mathrm{mg} / \mathrm{m}^{3}$ compared to the IDLH limit of $251,500 \mathrm{mg} / \mathrm{m}^{3}$. For $\mathrm{Hg}$, the air concentration at the site boundary is estimated to be $1.6 \times 10^{-2} \mathrm{mg} / \mathrm{m}^{3}$ compared to the IDLH limit of $28 \mathrm{mg} / \mathrm{m}^{3}$. For $\mathrm{Pb}$, the air concentration at the site boundary is estimated to be $0.16 \mathrm{mg} / \mathrm{m}^{3}$ compared to the IDLH limit of $700 \mathrm{mg} / \mathrm{m}^{3}$. Finally, the air concentration at the site boundary for $\mathrm{CrO}_{3}$ is estimated to be $8.4 \times 10^{-7} \mathrm{mg} / \mathrm{m}^{3}$ compared to the IDLH limit of $30 \mathrm{mg} / \mathrm{m}^{3}$.

As a result of this analysis, the chemical consequences of a fire outside the concrete culverts at the MWSB are not very significant.

To estimate the chemical consequences of a fire in the concrete culvert containing xylene, it is assumed that all 14 drums are involved. It is also assumed that the practice of placing xylene in a culvert without any other types of waste, as exhibited in Building 643-29E, will be followed at the MWSB; therefore, all 14 drums would contain xylene.

To find the air concentration at the site boundary for a xylene culvert fire, the release rate that was computed in the HAD fire analysis is used. From these calculations, the air concentration of xylene at the site boundary during a culvert fire is estimated to be 33.9 $\mathrm{mg} / \mathrm{m}^{3}$ compared to the IDLH limit of $4410 \mathrm{mg} / \mathrm{m}^{3}$.

As a result of this analysis, the chemical consequences of a xylene fire in the concrete culverts at the MWSB are not very significant.

\subsection{High Winds}

Sufficiently high winds can cause failure of the storage building, subsequent rupture of the storage containers, and some dispersion of the inventory. Since Building 643-43E is a low hazard facility, it is built to withstand wind speeds of about $84 \mathrm{mph}$. For this analysis, an 84 mph wind speed is argued capable of moving a 55-gallon drum with waste material inside it. Since the drums are banded together on each palette, the force necessary to move them is increased, so the analysis done here can be considered conservative.

\subsubsection{High Wind Frequency}

The frequency of $84 \mathrm{mph}$ straight winds at the Savannah River Site is reported to be $2.0 \mathrm{x}$ $10^{-2}$ per year. 
WSRC-TR-93-024

\subsubsection{High Wind Consequences}

The pallets most susceptible to damage from high winds are those located on the perimeter of Building 643-43E. Approximately 300 pallets are considered as potential candidates for high wind damage. Possible high wind damage includes drums rupturing from falling to the ground. For this analysis, it is assumed that $10 \%$ of the exposed pallets are blown to the ground. It is then assumed that 1 drum from each affected pallet is ruptured; therefore, the inventory adjustment factor for this analysis is found by divioing 30 by 3408. It is also assumed that $50 \%$ of the waste in the container spills out and, of that amount, $1 \%$ becomes airborne. Since the radionuclides stored outside of concrete culverts in Building 643-43E are

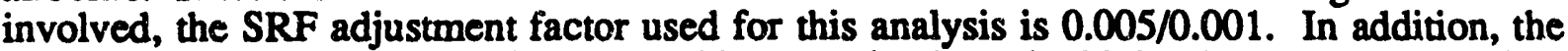
site boundary dose is also adjusted for this scenario since the high winds would provide a greater dispersal capability and would result in lower air concentrations. The adjustment consists of multiplying the $6.96 \times 10^{-3} \mathrm{REM}$ dose by the ratio of the $\chi / \mathrm{Q}$ value from the AXAOTHER calculation to the $\chi / Q$ value from the AXAIR-89Q calculation; this ratio corrects for the greater dispersal capability of the high velocity straight winds. With these assumptions, the following calculation is made to find the dose at the site boundary for a maximum exposed individual resulting from high wind damage to Building 643-43E:

$$
\begin{aligned}
& \begin{array}{l}
\text { Offsite max } \\
\text { individual dose }
\end{array}=\left(1.38 \times 10^{-5} \mathrm{REM}\right)(0.005 / 0.001)(30 / 3408) \\
& \begin{array}{l}
\text { Offsite max } \\
\text { individual dose }
\end{array}=6.1 \times 10^{-7} \mathrm{REM}
\end{aligned}
$$

The dose for the maximum exposed individual located 100 meters downwind of the facility is $2.0 \times 10^{-6} \mathrm{REM}$. The dose for the offsite population for this accident scenario is found to be $4.6 \times 10^{-5}$ Person-REM while the dose for the onsite population is $2.5 \times 10^{-6}$ Person-REM. (Consequences for this accident and other potential accidents evaluated for Building 643-43E are summarized in Table 1).

\subsubsection{High Wind Risk}

The risk for radiological release caused by damage to drums from high winds is characterized by the product of consequence and frequency. For the case of the maximum exposed individual at the site boundary, it is calculated to be $1.2 \times 10^{-8} \mathrm{REM} / \mathrm{yr}$. For the maximum exposed individual located 100 meters downwind of the facility, it is $4.0 \times 10^{-8} \mathrm{REM} / \mathrm{yr}$. For the offsite and onsite population, it is calculated to be $9.2 \times 10^{-7}$ Person-REM/yr and 5.0 $\mathrm{x}$ 10-8 Person-REM/yr respectively. (Risks for this accident and other potential accidents evaluated for Building 643-43E are summarized in Table 1).

\subsubsection{Chemical Consequences of High Winds}

The chemical consequences for the high wind scenario are not specifically calculated, but if they were, the procedure would be the same as that presented in the earthquake analysis. Referring to the chemical consequences for the earthquake scenario, the air concentrations found were well below the recommended IDLH limits. Since 30 drums would be involved in the high wind scenario, it is reasoned that the air concentrations would be even less than those found in the earthquake analysis which considered 50 drums. For this reason, the chemical consequences wer: not considered significant for the high wind accident. 
WSRC-TR-93-024

\subsection{Tornadoes}

Since Building $643-43 \mathrm{E}$ is a Low Hazard Facility, the design basis accidents do not include tornadoes [7]. For this reason, the risk associated with tornadoes was not calculated for this analysis.

\subsection{Criticality}

A potential criticality does not need to be evaluated since the maximum quantity of fissile material specified for the facility is less than $75 \%$ of the minimum critical mass. In addition, each B-25 container is limited to 150 grams of fissile material and drums stacked three high have less than 138 grams/container of fissile material.

\subsection{CONCLUSIONS}

Table 1 summarizes the information obtained from this analysis. Figures 1 and 2 display the individual accident risks presented by the storage of mixed waste in Building 643-43E relative to the other risks in the Burial Ground and the maximum risks from Building 643$43 E$ relative to the maximum risks for other SRS facilities, respectively. In both figures, the risks computed in this analysis are represented by a plus symbol

The total risk of radionuclide release from Building $643-43 E$ is determined to be $4.3 \times 10^{-5}$ REM/yr. These results compare favorably with the total Burial Ground maximum individual risk of $2.3 \times 10^{-3} \mathrm{REM} / \mathrm{yr}$. The low impact on risk is further illustrated by the graphic positions in Figures 1 and 2. (The risks from the Burial Ground SAR were revised from the ICRP-2 to the ICRP-30 Committed Dose Conversion Factors. In addition, the culvert fire scenario considered the current average inventory rather than the higher inventory used previously in the Burial Ground SAR).

In conclusion, the interim storage of hazardous waste/mixed waste in Building 643-43E does not represent a significant increase in the risks for the Burial Ground. 
WSRC-TR-93-024

\subsection{REFERENCES}

1. Corum, M. R., et. al., "Mixed Waste Storage Building, 643-43E, (Project S-2842) Hazards Assessment Document (U)," WSRC-TR-92-538, Westinghouse Savannah River Company, Aiken, SC, November 23, 1992.

2. Science Applications International Corporation, Safety Analysis - 200 Area Savannah River Plant Burial Ground Operations, DPSTSA-200-10, Sup-8, October, 1988.

3. Blume, J. A., Update of Seismic Criteria for the Savannah River Plant, Internal Report DPE-3699, E. I. du Pont de Nemours \& Co., Engineering Department, Wilmington, DE, 1982.

4. Huang, J. C., Natural Event Probabilities in Tabulated Forms, Internal Report DPST84-718 Sup-1, E. I. du Pont de Nemours \& Co., Savannah River Laboratory, Aiken, SC, November 19,1985.

5. Clewell, Harvey J., "A Simple Formula For Estimating Source Strengths From Spills of Toxic Liquids," Engineering \& Services Laboratory, Air Force Engineering \& Services Center, Tyndall Air Force Base, Florida, April, 1983.

6. $\quad$ Functional Performance Requirements - Byproduct/Tritiated Oil Storage Facility Building 643-43G," Rev. 3, NMP-WMP-91-4633, Westinghouse Savannah River Company, Aiken, SC, June 28, 1991.

7. Kennedy, R. P. et al, Design and Evaluation Guidelines For Department of Energy Facilities Subjected to Natural Phenomena Hazards, UCRL15910, October, 1989.

8. Elder, J. C., et al, A Guide to Radiological Accident Considerations for Siting and Design of DOE Nonreactor Nuclear Facilities, Los Alamos National Laboratory, LA10294-MS, January 1986. 


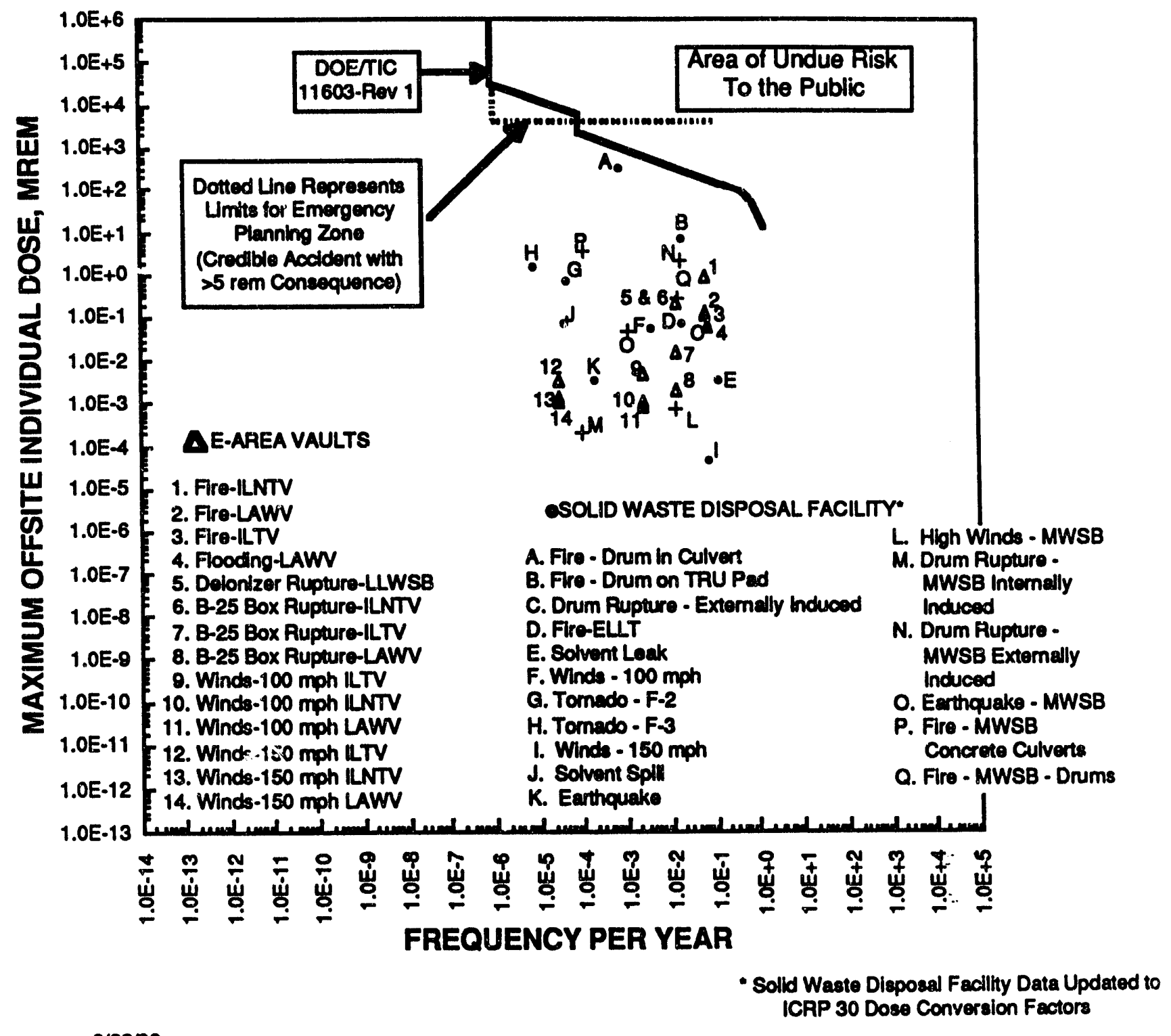

9/22/92

Figure 1. Risks of the Solid Waste Disposal Facility 


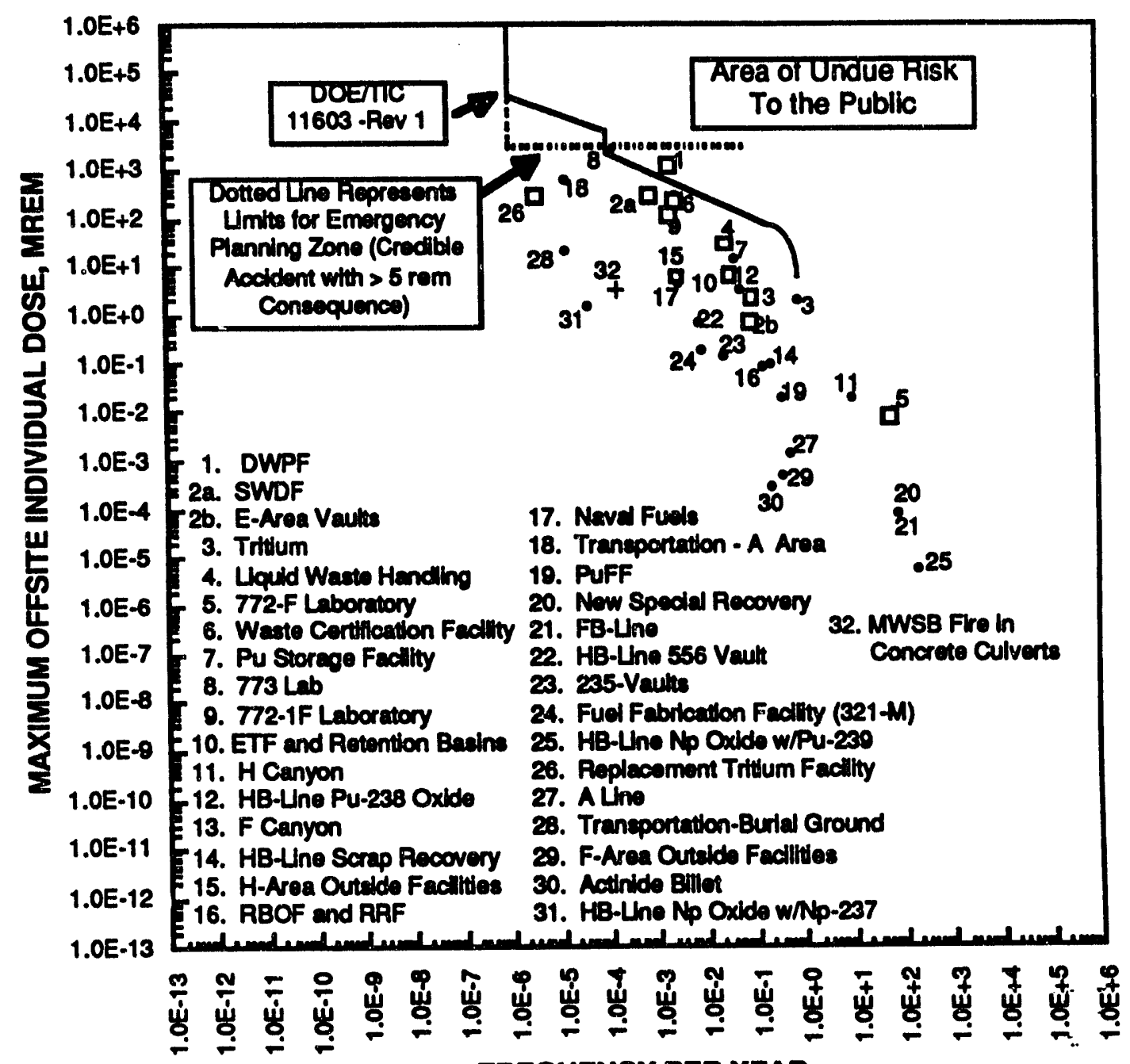

FREQUENCY PER YEAR 
WSRC-TR-93-024

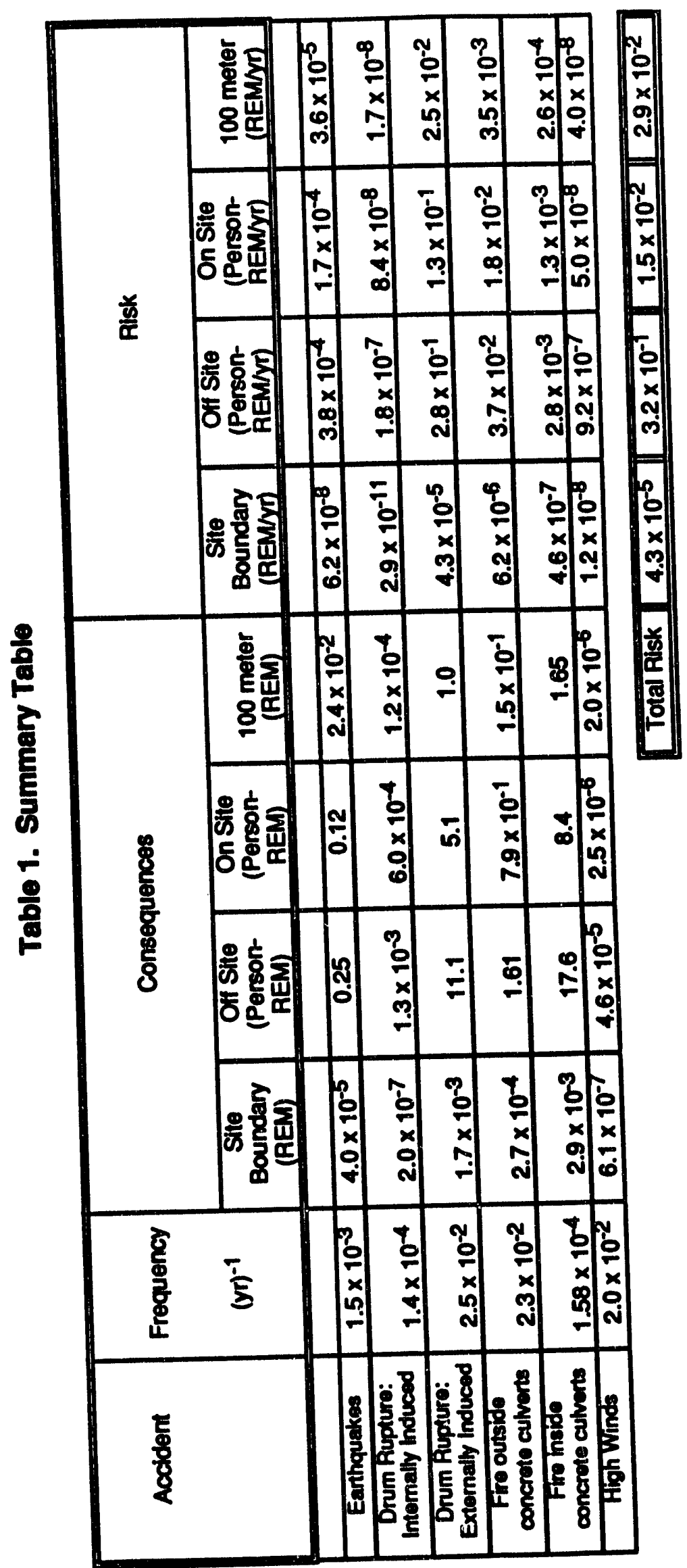



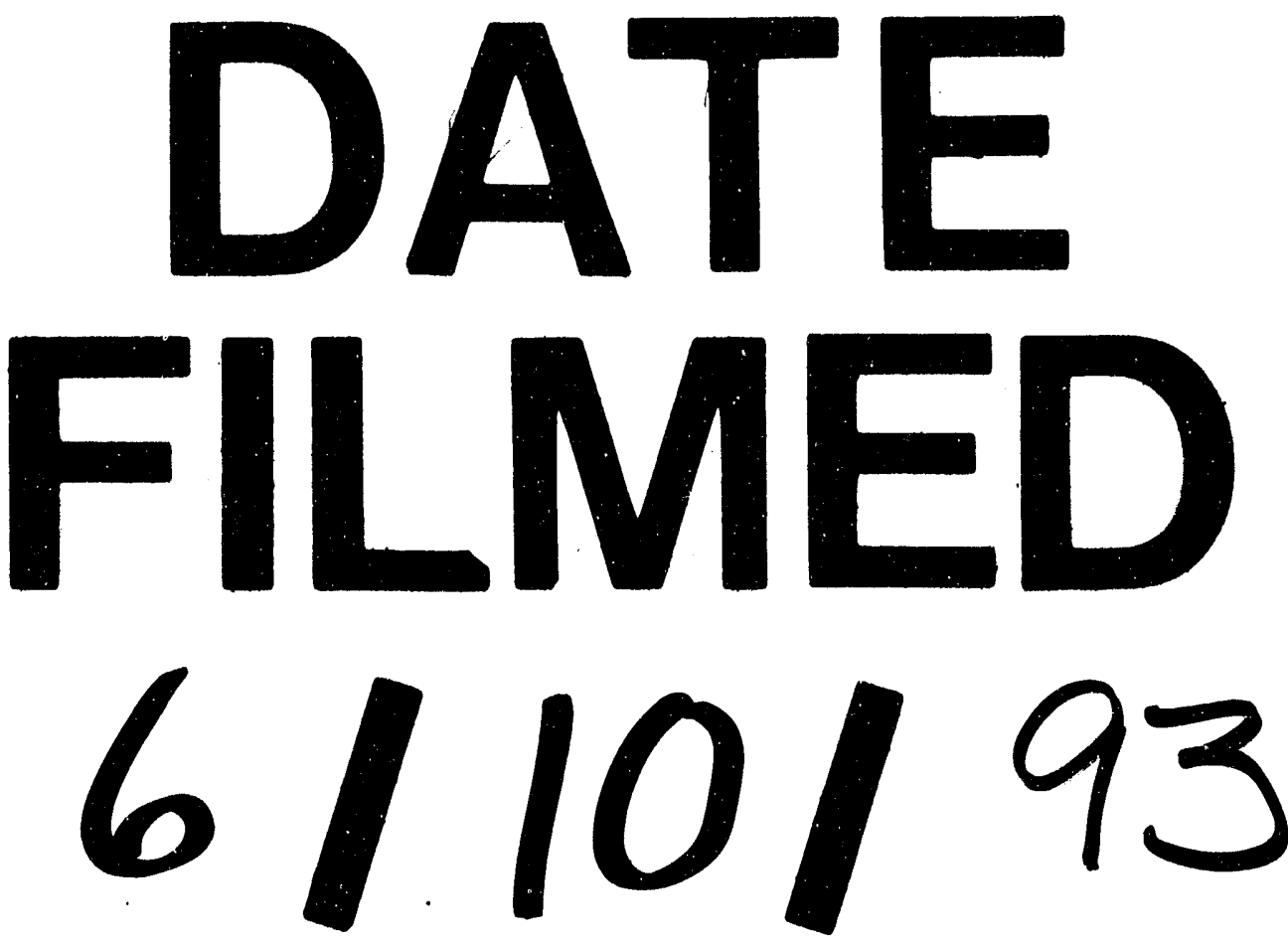
